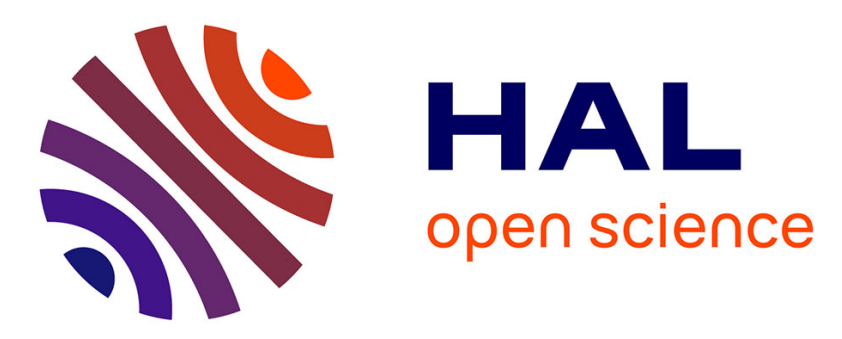

\title{
Genetic diversity of a marine foundation species, Laminaria hyperborea (Gunnerus) Foslie, along the coast of Ireland
}

Kathryn M Schoenrock, Aisha M O’Connor, Stéphane Mauger, Myriam Valero, João Neiva, Ester A. Serrao, Stacy A Krueger-Hadfield

\section{To cite this version:}

Kathryn M Schoenrock, Aisha M O'Connor, Stéphane Mauger, Myriam Valero, João Neiva, et al.. Genetic diversity of a marine foundation species, Laminaria hyperborea (Gunnerus) Foslie, along the coast of Ireland. European Journal of Phycology, In press, 10.1080/09670262.2020.1724338 . hal02550655

\section{HAL Id: hal-02550655 \\ https://hal.sorbonne-universite.fr/hal-02550655}

Submitted on 22 Apr 2020

HAL is a multi-disciplinary open access archive for the deposit and dissemination of scientific research documents, whether they are published or not. The documents may come from teaching and research institutions in France or abroad, or from public or private research centers.
L'archive ouverte pluridisciplinaire HAL, est destinée au dépôt et à la diffusion de documents scientifiques de niveau recherche, publiés ou non, émanant des établissements d'enseignement et de recherche français ou étrangers, des laboratoires publics ou privés. 
Genetic diversity of a marine foundation species, Laminaria hyperborea (Phaeophyceae Laminariales), along the coast of Ireland

Kathryn M. Schoenrock ${ }^{1 * \#}$, Aisha M. O’ Connor ${ }^{1,4^{*}}$, Stéphane Mauger ${ }^{2}$, Myriam Valero $^{2}$, João Neiva $^{3}$, Ester Á. Serrão ${ }^{3}$, and Stacy A. Krueger-Hadfield ${ }^{4 \#}$

${ }^{1}$ Botany and Plant Sciences, Ryan Institute, National University of Ireland Galway, University Road, Galway, Ireland, H91 TK33

${ }^{2}$ UMI EBEA 3614, CNRS, Sorbonne Université, UC, UACH, Station Biologique de Roscoff, Place Georges Tessier CS 90074, 29688, Roscoff, France

${ }^{3}$ Centro de Ciências do Mar, Universidade do Algarve, Campus de Gambelas, 8005-139 Faro,

Portugal

${ }^{4}$ University of Alabama at Birmingham, Department of Biology, Campbell Hall, Rm 464, 1300

University Rd., Birmingham, AL, 35294 USA

*Shared first authors

\#Authors for correspondence: Kathryn M. Schoenrock Kathryn.schoenrock@ nuigalway.ie; Stacy

A. Krueger-Hadfield sakh@uab.edu

Running title: Genetic structure in Irish Laminaria hyperborea 


\section{ABSTRACT}

Worldwide, kelp populations are stressed by warming, increased storms and other anthropogenic disturbances. Marine population distributions are projected to retreat poleward with climate change if they cannot adapt to changing conditions, which would potentially lead to a regime shift in subtidal habitats. In Northern Europe, Laminaria hyperborea is a subtidal ecosystem engineer whose distribution has shifted over millennia, leaving predicted areas of high genetic diversity from the last glacial maximum (LGM) near its southern distribution limit in the Iberian Peninsula. In Ireland, L. hyperborea structures communities by supporting diverse faunal assemblages and producing large quantities of organic carbon throughout the year. We investigated the genetic diversity of eight populations, ranging from the southern coast to the northwest of Ireland, using nine microsatellite loci. Diversity was found to be highest in Lough Hyne, a Special Area of Conservation (SAC), near the predicted climate refugium. We found evidence of isolation by distance, with high connectivity between populations that were geographically close, probably driven by short range dispersal of L. hyperborea propagules. Genetic diversity (measured as expected heterozygosity and allelic richness) was highest at Lough Hyne, and decreased northwards, as predicted from past range shifts. Expected heterozygosity was highest at Lough Hyne (0.706) and decreased northward, with the lowest value at Bridges of Ross (0.283). Based on these patterns, further fine-scale investigation into population diversity, dispersal and potential resilience in Irish kelp forests are necessary as warming and non-native species are observed more and more frequently.

Keywords: Boreal, climate refugia, dispersal, kelp, microsatellites, population genetics, resilience, species distribution 
Introduction

Kelp form important near-shore marine habitats that provide structural support for diverse biological assemblages (including algae and fauna; Bustamante \& Branch, 1996; Graham, 2004; Udy, 2019; Howard, 1980; Herrnkind \& Butler, 1986; Lowry \& Pearse, 1973; Won et al., 2013), and are also a primary resource consumed locally or exported to adjacent communities (Kain, 1979; Dayton, 1985; Kaehler et al., 2006; Filbee-Dexter \& Wernberg, 2018). In addition, kelp forest ecosystems provide protection to coastal habitats and subsidies to terrestrial environments (Barbier et al., 2008; Krumhansl \& Scheibling, 2012; Mineur et al., 2015). The stability and diversity of kelp forests varies depending on foundation species (Bertocci et al., 2015), location (region and exposure gradient; Burrows et al., 2008), and even variation from edge to centre within a forest (Dayton 1985). These universally important ecosystem engineers and resources are in flux across their distribution (Krumhansl et al., 2016), and are threatened by a variety of natural stressors, such as sea urchin grazing (Estes \& Duggins, 1995), and anthropogenic pressures, such as warming oceans (Wernberg et al., 2016) and harvesting (Lorentsen et al., 2010).

In the northeast Atlantic subtidal kelp forests are dominated by stipitate Laminariales, predominantly cold-temperate L. hyperborea (Gunnerus) Foslie from the Iberian Peninsula northwards (Araujo et al., 2016), including Ireland, and warm-temperate Laminaria ochroleuca Bachelot de Pylaie from Morocco to Brittany, France and although L. ochroleuca sometimes forms a large canopy in sheltered and deeper habitats in northerly locations shared with other Laminaria spp. (John, 1969; Sheppard et al., 1978). Laminaria hyperborea communities are characterized by greater diversity in marine assemblages (Teagle \& Smale, 2018), therefore the generally negative response of kelp forests to climate change, especially ocean warming and 
heatwaves, raises concerns that their populations, and therefore ecological role in the coastal and deep sea, may be threatened (Filbee-Dexter et al., 2018). These incredibly rich environments are compromised via reduced quality and quantity of organic carbon in food webs (Pessarrodona et al., 2018) and reduced habitat area (Wernberg et al., 2011). When combined with harvesting pressure, the effect of which takes Norwegian (L. hyperborea) and French (L. hyperborea and $L$. digitata) kelp forest ecosystems over five years to recover from (Lorentsen et al., 2010; Leclerc et al., 2015), anthropogenic stressors may outpace the recovery of these habitats, posing a real threat to kelp forest persistence in Europe (Araujo et al., 2016). For this reason, it is essential to document ecological and evolutionary characteristics intrinsic to the resilience of these communities to better manage and monitor changes.

Successful recruitment, growth and competition (kelp-kelp, kelp-macroalgae, and kelpfaunal) collectively influence the development and establishment of kelp forests. Laminaria spp. in Europe have varied reproductive timing. In L. hyperborea, individuals are fertile from October through to early April (Kain, 1979; K.M. Schoenrock personal observation), producing zoospores (50:50 male and female gametophytes) which become fertile and have greater survivorship in waters $<17^{\circ} \mathrm{C}$ (Kain \& Jones, 1964), an important consideration in terms of competition with congeneric species that are reproductive in summer (Kain \& Jones, 1969). Zoospores are motile for $>20$ hours after sporulation and can potentially disperse up to $300 \mathrm{~m}$ from their origin, and gametophytes can remain viable for $>80$ days in darkness (Kain \& Jones, 1964, 1969; Fredriksen et al., 1995). Very little light is needed for gametophyte development $\left(0.0962 \mu \mathrm{mol}\right.$ photons $\mathrm{m}^{-2} \mathrm{~s}^{-1}$ at $\left.10^{\circ} \mathrm{C}\right)$, although optimal irradiance for maturation and growth is between $6.105-7.4 \mu \mathrm{mol}$ photons $\mathrm{m}^{-2} \mathrm{~s}^{-1}$ at colder temperatures (at $17^{\circ} \mathrm{C}$ saturation levels are above $37 \mu$ mol photons $\mathrm{m}^{-2} \mathrm{~s}^{-1}$; Kain \& Jones, 1964). Field observations show juvenile kelps are 
in highest abundance from spring to summer but can be present year-round, which may indicate gametophyte or sporophyte dormancy in the understory throughout the year (Kain, 1976; K.M. Schoenrock, personal observation).

Based on observed dispersal distances in conjunction with life history characteristics, gene flow is expected to be spatially restricted and genetic differentiation likely to increase with increasing distance in kelps (see as examples Billot et al., 2001; Robuchon et al., 2014). At small scales, the distance between reproductive structures on a thallus or blade relative to the substratum further influences dispersal distance as there are different flow velocities throughout the vertical water column (Norton, 1992), especially in dense algal communities (Denny, 1988; Stevens et al., 2003). Turbulent water flow is found closer to the substratum, where water movement slows and interacts with a benthic boundary layer which has unique chemical, physical, and biological composition, suitable for macroalgal propagules and other marine microorganisms (Amsler et al., 1992). In L. digitata and L. hyperborea, gametophyte dilution poses a major limitation to kelp propagation, but sori on blades of both kelp species are 1-3 m above the substratum, which is thought to increase dispersal distance (Robuchon et al., 2014). It has been proposed that kelp blades may aid gamete dispersal further, acting as paddles to increase water movement locally (Robuchon et al., 2014).

At medium and large scales (i.e., within, among and between sites), adult sporophytes can be detached and, if reproductive, shed zoospores in new habitats (Collins et al., 2010), or non-reproductive, drifting fronds can become mature several weeks after being detached (de Bettignies et al., in revision) enhancing otherwise limited spore dispersal (Norton, 1992). Spore clouds may also be a mode of mass spore dispersal (Norton, 1992). Dispersal by animals may also occur, as was demonstrated in Lessonia nigrescens, where viable zoospores were found in 
the faeces of the marble fish Aplodactylus punctatus in Chile (Ruz et al., 2018). Dispersal in European kelps has not been thoroughly investigated, however in local studies both Billot $e t$ al. (2003) and Robuchon et al. (2014) detected patterns of isolation by distance (IBD) in L. digitata and L. hyperborea along the Brittany coastline. This local effect is also present in L. ochroleuca (Assis et al., 2018), S. polyschides (Assis et al., 2016, 2017) and S. latissima (Neiva et al., 2018), although at geographic scales all studies show that the effects of past range shifts predominate over IBD in structuring European kelp populations. Robuchon et al. (2014) noted reduced gene flow and increased population differentiation at a scale of $10-15 \mathrm{~km}$ in subtidal L. hyperborea and intertidal $L$. digitata. Populations of $L$. hyperborea were not only more diverse, but also more connected than populations of $L$. digitata, probably due to characteristics of the subtidal vs. intertidal environment, respectively.

Billot et al. (2003) and Robuchon et al. (2014) studies in Brittany were focused in areas of intense kelp harvest, in which an understanding of genetic diversity is paramount to better management practices (Valero et al., 2017) and required to understand the effects of genetic diversity on fitness (see as example Hoezel et al., 2002). As in north western France, Ireland has a long history of macroalgal economy, and kelp and other seaweeds are regularly harvested for use in multiple industries and used in local foods (Mac Monagail et al., 2018). The potential for upscaling the seaweed economy in this region makes the productivity, diversity and genetic makeup of these communities important to understand. During the last glacial maximum (LGM, 26-19 Ka BO), the distribution of L. hyperborea was predicted to range from Iceland, the Faroe Islands and Southern Ireland through to Western Iberia and Morocco (Assis et al., 2016). Regions of long-term population persistence (i.e. climatic refugia), such as southern Ireland, where glacial and modern ranges overlap, are predicted to host high genetic diversity (Haffer, 
1982), but the hypothesis that refugia have higher genetic diversity and potentially resilient alleles has not yet been tested for this region and cannot be assessed with modelling approaches. Refugial populations, especially if they are composed of unique allelic diversity, are of great interest because kelp distributions are predicted to retreat northwards as oceans warm, with an estimated 33.62\% loss of suitable habitats in Europe (Assis et al., 2018) significantly affecting coastal ecology and economy. Already, decreases in L. hyperborea from levels recorded in 1954 have been noted in intertidal surveys in Ireland (Simkanin et al., 2005). In contrast, subtidal populations have either increased or remained stable in Ireland over the past 40 years (Yesson et al., 2015a), and habitat suitability models indicate they may be more impacted by substrata suitability (Yesson et al., 2015b). Few studies have explored genetic structure and connectivity of marine species along the Irish coast and most include few sample sites making it difficult to discern patterns of genetic diversity and structure at a finer scale (Bell \& Okamura, 2005; Olsen et al., 2010). Taking into consideration the ecological, evolutionary, and economic relevance of L. hyperborea in Ireland, we investigated its regional genetic landscape. In this study, we sought to (i) characterize patterns of genetic diversity, (ii) describe the mating system, and (iii) assess population connectivity of L. hyperborea along Irelands reticulated coastline in order to test the occurrence of genetic barriers to gene flow.

\section{Materials and Methods}

Sample collection

Blades of L. hyperborea were collected from eight sites along the Irish coastline between July, 2017 and June, 2018 (Table 1; Fig. 1). Kelp was collected from dense forests at $\sim 6 \mathrm{~m}$ depth using SCUBA at all sites except 'the rapids' at Lough Hyne, County Cork, where snorkelers 
collected blades during slack water, ebb tide. In the lab, blades $(n=19-25)$ were wiped clean of epiphytes and blotted dry, then $2 \mathrm{~cm}^{2}$ of tissue close to the apical meristem was collected and preserved in silica gel for subsequent DNA extraction.

DNA extraction, PCR conditions, and fragment analysis

Approximately $12 \mathrm{mg}$ of silica-dried tissue (19-25 samples per site; Table 2) was placed in 1.5 $\mathrm{ml}$ microcentrifuge tubes, flash frozen at $-80^{\circ} \mathrm{C}$ for $10 \mathrm{~min}$, and freeze dried (Lyph-Lock 12 Litre model 77540, Labconco Corp., Kansas City, Missouri, USA). Samples were then ground with $2.8 \mathrm{~mm}$ ceramic beads using a bead mill (BeadMill24, Fisher Scientific, Waltham, Massachusetts, USA). We were able to grind freeze-dried tissue better than tissue dried in silica gel, thereby increasing DNA yields. Total genomic DNA was extracted using the Nucleospin® 96 Plant Kit (Macherey-Nagel, Düren, Germany) according to the manufacturer's instructions, except for the lysis step in which samples were incubated for $1 \mathrm{~h}$ at room temperature. DNA was eluted once in $100 \mu \mathrm{l}$ of molecular grade deionized water.

Six microsatellite loci previously developed for L. digitata (Ld148, Ld158, Ld167, Ld531, Ld704; Billot et al., 1998) and six loci developed for L. ochroleuca (LoIVVIV-23, LoIVVIV-17, LoIVVIV-28, LoIVVIV-27, LoIVVIV-24; Coelho et al., 2014) were used. We amplified locus Ld531 in a simplex PCR and the remaining loci in three multiplexes (M1: Ld148, Ld158, Ld167; M2: LoIVVIV-17, LoIVVIV-24; M3: LoIVVIV-23, LoIVVIV-28, LoIVVIV-27). The L. digitata loci were amplified in a PCR program including initial denaturation at $94^{\circ} \mathrm{C}$ for $5 \mathrm{~min}$, five cycles of touchdown PCR (denaturation at $94^{\circ} \mathrm{C}$ for $45 \mathrm{~s}$, annealing at $60^{\circ} \mathrm{C}$ for $1 \mathrm{~min}$, and extension at $72^{\circ} \mathrm{C}$ for $45 \mathrm{~s} ; 1^{\circ} \mathrm{C}$ decrease in annealing temperature every cycle) followed by 30 cycles of denaturation at $94^{\circ} \mathrm{C}$ for $45 \mathrm{~s}$, annealing at 
$55^{\circ} \mathrm{C}$ for $45 \mathrm{~s}$ and extension at $72^{\circ} \mathrm{C}$ for $1 \mathrm{~min}$, ending with extension at $72^{\circ} \mathrm{C}$ for $30 \mathrm{~min}$ following Robuchon et al. (2014) using either SimpliAmp or ProFlex thermocyclers (Applied Biosystems, Foster City, California, USA). We used a $10 \mu$ final volume containing $1 \mathrm{X}$ GoTaq® Flexi colourless reaction buffer (Promega Corp., Madison, WI, USA), 1.5 mM MgCl 2 , $250 \mu \mathrm{M}$ of each dNTP, 0.5 units of GoTaq ${ }^{\circledR}$ DNA polymerase (Promega Corp.), fluorescently labelled forward primer (see Supplementary table 1), unlabelled reverse primer (see Supplementary table 1), and $2 \mu \mathrm{l}$ of template DNA (diluted to 1:100).

With the $L$. ochroleuca primers, we used a $10 \mu$ final volume containing $1 \mathrm{X}$ GoTaq ${ }^{\circledR}$ Flexi colourless reaction buffer (Promega Corp., Madison, Wisconsin, USA), $1.5 \mathrm{mM} \mathrm{MgCl}$, $250 \mu \mathrm{M}$ of each dNTP, 0.5 units of GoTaq ${ }^{\circledR}$ DNA polymerase (Promega Corp.), fluorescently labelled forward primer (see Supplementary table 1), unlabelled reverse primer (see Supplementary table 1), and $2 \mu$ l of template DNA (diluted to 1:100). The PCR program included an initial denaturation step at $95^{\circ} \mathrm{C}$ for 5 min followed by 35 cycles of denaturation at $95^{\circ} \mathrm{C}$ for $30 \mathrm{~s}$, annealing at $60^{\circ} \mathrm{C}$ for $30 \mathrm{~s}$ and extension at $72^{\circ} \mathrm{C}$ for $45 \mathrm{~s}$, ending with extension at $72^{\circ} \mathrm{C}$ for $20 \mathrm{~min}$.

One $\mu \mathrm{l}$ of each PCR product was added to a loading buffer containing 9.7 $\mu \mathrm{l} \mathrm{Hi-Di}$ Formamide and $0.35 \mu \mathrm{l}$ of size standard (GeneScan500 Liz; Applied Biosystems, Foster City, California, USA). Samples were electrophoresed on an ABI 3730xL genetic analyser equipped with a 96-capillary array (Applied Biosystems). Raw alleles were scored manually in two independent scorings using GENEIOUS PRIME 2019.0.3 (https://www.geneious.com) and allele sizes were binned with TANDEM software (Matschiner \& Salzburger, 2009). Microsatellite loci whose average rounding error was below $10 \%$ of the repeat size, as assessed by TANDEM 
(Matschiner \& Salzburger, 2009), are useful for subsequent analyses. We manually checked poorly binned alleles, following Krueger-Hadfield et al. (2013, 2016).

Fragment analysis, calibration across sequencing platforms, and allele calling As reviewed by Matschiner \& Salzburger (2009), there are a myriad of ways in which inconsistencies can arise in microsatellite allele binning in which allele sizes from a capillary sequencer are given as a number to two decimal places. Simple rounding, for example, can lead to even and odd alleles in the same locus or, alternatively, the merging of alleles which may cause an underestimate of allelic richness. Likewise, different labs may bin alleles in different ways, rendering it very difficult to combine data sets across labs as the same allele may be binned differently in each lab artificially deflating or inflating allelic diversity.

In order to combine data across labs that have genotyped $L$. hyperborea, we amplified a subset of individuals that had a range of the alleles present from fragment analysis conducted at the Heflin Center for Genomic Sciences at the University of Alabama at Birmingham (UAB) using simplex PCRs and the previously described PCR programs and mixes for the L. digitata and $L$. ochroleuca loci (Supplementary table 2). PCR products were electrophoresed on the same capillary sequencer at UAB as described above. PCR products were added to the same Hi-Di Formamide and GS500 Liz mix as described above and shipped to the UMI3614 EBEA at the Station Biologique de Roscoff (SBR) and at the Centro de Ciências do Mar, Universidade do Algarve (CCMAR). PCR products were then electrophoresed on an ABI PRISM capillary sequencer 3130XL Genetic Analyzer at SBR and CCMAR.

At UAB, alleles were scored using GENEIOUS PRIME 2019.0.3 and TANDEM as described above. At SBR, alleles were manually scored and binned using GENEMAPPER 
version 4 (Applied Biosystems) and following previously published allele calls from Robuchon et al. (2014). At CCMAR, alleles were scored manually using STRand - Nucleic Acid Analysis Software (Toonen \& Hughes, 2001; https://www.vgl.ucdavis.edu/informatics/faq_strand.php). Alleles were then rounded up or down depending on the allele size.

We then compared the raw and called alleles from the three sequencing platforms. As data are already published using allele bins by SBR, we binned alleles following the bins from SBR. For other alleles not scored at SBR or CCMAR, we used the repeat motif of the specific locus in conjunction with the other alleles scored across platforms to bin the remaining alleles (Supplementary table 2).

\section{Genetic and genotypic diversity}

The frequency of null alleles was estimated using ML-NullFreq (Kalinowski \& Taper, 2006) with 100 randomizations. Krueger-Hadfield et al. (2013) compared direct null allele frequency estimates from non-amplification of loci in haploid thalli to estimates from maximum likelihood estimators, such as the ones used in ML-NullFreq, in diploid thalli in Chondrus crispus. They found that due to deviations from Hardy-Weinberg expectations as a result of non-random mating, maximum likelihood estimators can be biased because they assume Hardy-Weinberg conditions.

The number of repeated identical multilocus microsatellite genotypes (MLGs) was computed using RClone (Bailleul et al., 2016) in $R$ ver. 3.3.0 (R Core, 2018). The frequency of different MLGs was calculated as: $R=(\mathrm{G}-1) /(N-1)$, where $G$ is the number of unique multilocus genotypes and $N$ is the total number of studied individuals (Dorken \& Eckert, 2001). $P_{s e x}$, which is the probability for a given MLG to be observed in $N$ samples because of different 
sexual reproductive events, was calculated for each repeated MLG. If $P_{\text {sex }}$ was greater than 0.05, duplicated multilocus genotypes were considered as different genets. If $P_{\text {sex }}$ was smaller than 0.05, the duplicated MLGs were considered as ramets (or clones) of the same genet.

Gametic disequilibrium was evaluated using the single multilocus estimate $\overline{r_{d}}$ (Agapow \& Burt, 2001) and implemented in the $R$ (R Core, 2018) package poppr ver. 2.0.2 (Kamvar et al., 2014, 2015). In order to test for departure from random associations between loci, the observed data set was compared to 1000 simulated datasets in which sex and recombination was imposed by randomly reshuffling the alleles among individuals for each locus (Agapow \& Burt, 2001) followed by Bonferroni correction (Sokal \& Rohlf, 1995). The two alleles of the same locus were shuffled together to maintain associations between alleles within loci in the randomized dataset. In addition to physical linkage on a chromosome, disequilibria may be due to a lack of recombination caused by selfing (mating system) or to differences in allele frequencies among populations (spatial genetic structure).

For each site, the average expected heterozygosity $\left(\mathrm{H}_{\mathrm{E}}\right)$ and observed heterozygosity's $\left(\mathrm{H}_{\mathrm{O}}\right)$ were calculated using GenAlEx ver. 6.5 (Peakall \& Smouse, 2006, 2012). An estimate of the mean expected number of alleles $\left(\mathrm{A}_{\mathrm{E}}\right)$ and the mean number of private alleles $\left(\mathrm{P}_{\mathrm{A}}\right)$ were computed using the program HP-Rare ver. 1.0 (Kalinowski, 2005) on the smallest sample size of 19 sporophytes (i.e., 38 alleles). Tests for Hardy-Weinberg equilibrium (HWE) were performed using FSTAT, ver. 2.9.3.2 (Goudet, 1995). $F_{\text {IS }}$ was calculated for each locus and over all loci according to (Weir \& Cockerham, 1984) and significance was tested by running 1000 permutations of alleles among individuals within samples.

Genetic structure and gene flow 
We calculated pairwise genetic differentiation for each pair of sites as $F_{S T}$ in Genodive ver. $2.0 \mathrm{~b} 23$ (Meirmans \& van Tienderen, 2004). We measured geographic distance $(\mathrm{km})$ following the contours of each coastline between all site pairs using the measure distance function in Google ${ }^{\circledR}$ Maps. We performed Mantel tests in order to detect relationships between the genetic and geographic distance (Isolation by Distance, IBD) along each of the four coastlines using $R$ (R Core, 2018). As suggested by Rousset (1997), when sampling at a two-dimensional scale we plotted $F_{S T} /\left(1-F_{S T}\right)$ against the logarithm of the geographic distance $(\mathrm{km})$.

To assess relationships among sites, we used a discriminant analysis of principal components (DAPC) implemented in the $R$ package adegenet, ver. 2.0.1 (Jombart, 2008; Jombart \& Ahmed, 2011). DAPC is a multivariate analysis that avoids making strong assumptions about the underlying genetic model (Jombart et al., 2009) and finds the principal components that best summarize the differences among clusters, while also minimizing within-cluster variation (Jombart et al., 2010). The procedure first generates a principal component analysis (PCA) on pre-defined groups (see below). These PCs were, then, used as variables for a discriminant analysis that maximizes the inter-group component of variation.

We divided our sites into two sets of a priori groups based on the county in which the sites were found: (set 1) Cork (HYN, ZET), Clare (BOR, NFY), Galway (NEQ, LMN, ACR), and Donegal (SJP); (set 2) Cork (HYN, ZET), Clare (BOR, NFY), Galway (NEQ), Galway coastal (LMN, ACR), and Donegal (SJP). For each set, we performed the DAPC with increasing numbers of PCs on $90 \%$ of our data and then the remaining $10 \%$ of the individuals were projected onto the discriminant axes constructed by the DAPC. It was possible to measure how accurately the remaining $10 \%$ of the individuals were placed in multidimensional space (i.e., how well their position corresponds to their group membership). Based on this cross-validation 
with the xvalDapc function, we retained: (set 1) 16 principal components (PC) that explained $82.3 \%$ of the total variance for subsequent DAPCs; (set 2) 18 principal components (PC) that explained $85.0 \%$ of the total variance for subsequent DAPCs.

We estimated how well-supported the group membership was relative to our two sets of $a$ priori groups using the compoplot function in adegenet. Posterior group memberships were utilized in order to indicate admixture or the misclassification when prior groups are used to conduct the DAPC.

We also used a Bayesian model-based clustering algorithm that relaxes the HWE assumption as implemented in the software instruct (Gao et al., 2007). Simulations were performed using instruct with a model including both bi-parental inbreeding and admixture, where each individual drew some fraction of its genome from each of the $K$ populations. A burnin of 200000 repetitions and a run length of 100000 were used for $K=2$ to $K=10$, where 10 chains were run for each $K$ (instruct command line: -N 180 -L 9 -lb 1 -a 1 -x 0 -w 1 -p 2 -m -9 -k 8 -af 1 -mm 9.09e9 -v 1 -ik 1 -kv 210 -c 10 -u 200000 -b 100000 -t 10 -g 1 -r 2000 -e 0 -f 0 -pi 0 -pf 0 -j 2000 -df 1 -s1 0.9 -s 2422530 40).

To evaluate the values of $K$, we analysed $K=2$ to 10 clusters using the programme clumpak (Kopelman et al., 2015). The programme clumpak identifies sets of highly similar runs across the 10 independent chains of each $K$ generated with instruct and separates them into distinct major and minor modes. It utilizes the software clump (Jakobsson \& Rosenberg, 2007) in order to generate a consensus solution for each distinct mode using a Markov clustering algorithm that relies on a similarity matrix between replicate runs. Next, clumpak identifies an optimal alignment of inferred clusters and matches the clusters across the values of $K$ tested. The major mode has the largest number of replicate chains, while the minor modes have fewer 
replicate chains. We determined the optimal number of $K$ using outputs from instruct and clumpak. First, we plotted the number of clusters against the values of DIC $( \pm$ SE) and chose the value of $K$ at the point at which the curve reached an asymptote. The lower the DIC value, the better fit of the model used (i.e., the number of K). Second, we used the number of independent chains out of 10 that generated the major mode and the highest mean similarity score from clumpak.

\section{RESULTS}

Microsatellite amplification, binning across platforms, and null alleles

All loci exhibited errors below $10 \%$ of the repeat size (Supplementary table 1). There were some slight discrepancies in raw allele sizes between the capillary sequencers at UAB and CCMAR versus SBR (Supplementary table 2). However, there were no alleles in which we could not confidently score using the existing SBR bins that had been utilized for previous work on $L$. hyperborea (Robuchon et al., 2014).

We removed seven individuals that had three or more loci that did not amplify after at least two PCR attempts (HYN_10, HYN_03, HYN_24, NEQ_16, NEQ_14, NEQ_24, BOR_01, and ZET_16).

Though there was evidence of null alleles at some of the loci and in some of the populations, the frequencies were generally low, ranging anywhere from zero to less than $20 \%$ across all sites with the exception of locus LoIVVIV-27 at An Cheathrú Rua (24\%). Because of the aforementioned problems (see Methods) with using maximum likelihood estimators and the generally low frequency across sites at the loci, we used all nine loci for all subsequent analyses (Supplementary table 3). 
The number of alleles per locus ranged from 6 to 17 (Supplementary table 1) for a total of 106 alleles detected across 180 individuals at nine loci (Supplementary table 3).

Patterns of genetic diversity and mating system

There were repeated multilocus genotypes in Bridges of Ross (BOR), An Cheathrú Rua (ACR), Newfy (NFY), and St. John's point (SJP). However, only the pairs at An Cheathrú Rua and St. John's Point had $P_{\text {sex }} p$-values of less than 0.05 (Table 2, Supplementary table 4). When based on a sample size of 19 diploid sporophytes (38 alleles), the allelic richness ranged from 2.52 at the Zetland pier (ZET) to 8.17 at Lough Hyne. The private allelic richness was 4.48, at Lough Hyne, but was $<1$ at all other sites (Table 2, Fig. 2, Supplementary table 5). Expected heterozygosity varied from 0.283 at the bridges of Ross to 0.706 at Lough Hyne.

There was evidence of gametic disequilibrium at Lough Hyne based on the multilocus estimate of (Table 2). Likewise, we found an excess of homozygotes at Lough Hyne and New Quay (NEQ) based on FIS.

Patterns of genetic structure and gene flow along the Irish coast Global analyses of genetic structure revealed significant genetic differentiation as measured by $F_{S T}$ (26 of 28 pairwise comparisons [i.e., 93\%], Supplementary table 6). Genetic distance ranged from 0.011 to 0.434 (average $=0.219)$. At distances of approximately $20 \mathrm{~km}$, pairwise comparisons of genetic differentiation were not significantly different from zero between An Cheathrú Rua (ACR) and Leitir Mealláin (LMN) in County Galway or Bridges of Ross and Newfy (NFY) in County Clare. The smallest geographic distance at which there was significant genetic differentiation occurred at approximately $80 \mathrm{~km}$ between Leitir Mealláin and New Quay 
in County Galway. There was a range of genetic distances observed for similar geographic distances (Fig. 3, Supplementary table 6), but with an overall pattern of significant IBD (Fig. 3). Microsatellite genotypes differentiated the L. hyperborea populations found in each of the four Irish counties. This separation was evident along the $1^{\text {st }}$ axis of the DAPC, which itself explained $\sim 45 \%$ of the overall variation (Fig. 4). The stability of a priori group membership probabilities, derived from proportions of successful reassignments based on retained discriminant functions of DAPC, were high (> 98\%) when we used four a priori groups of Counties Donegal, Galway, Clare, and Cork (Supplementary fig. 1a). When we separated the coastal sites of An Cheathrú Rua and Leitir Mealláin from New Quay in County Galway, there was only $83 \%$ reassignment to New Quay in which many sporophyte genotypes were assigned to the subregion, including An Cheathrú Rua and Leitir Mealláin. Likewise, some of An Cheathrú Rua and Leitir Mealláin sporophytes were assigned to New Quay, suggesting gene flow occurred between these sites, but is probably restricted between New Quay and the two other Galway sites.

Similar patterns of genetic structure were found using the Bayesian clustering algorithm instruct. At $K=6$, the optimal number of genetic clusters determined by the curve of DIC estimates (Supplementary fig. 2a), the mean similarity score computed using clumpak (0.995), and the total number of chains that produced the major mode (10/10, see also Krueger-Hadfield et al., 2017). St. John's Point was clearly different from the other sites in this study and was dominated by one genetic cluster (shown in turquoise in Fig. 5). The three Galway sites also were dominated by one major genetic cluster (shown in red in Fig. 5), but there were individuals that showed admixture with the genetic clusters that dominated Counties Clare and Cork (orange and blue-dark green respectively in Fig. 5). Zetland Pier, which clustered with Lough Hyne in 
DAPC analyses, was dominated by a different genetic cluster than that found in Lough Hyne (shown as blue versus green in Fig. 5). However, Lough Hyne had several individuals that were composed of the genetic clusters that dominated Newfy and Bridges of Ross, as well as Zetland Pier. All other clusters are provided in Supplementary fig. $2 \mathrm{~b}-\mathrm{m}$.

\section{DISCUSSION}

This study is the first to explore genetic diversity and structure of Laminaria hyperborea along a latitudinal gradient in Ireland. We found patterns of IBD and strong genetic structure along the Irish coast, similar to previous descriptions for this species along the coastline of Brittany (Robuchon et al., 2014) and in Norway (Evankow et al., 2019). The highest genetic diversity and private alleles (potentially a 'refuge' from the LGM) were described in Lough Hyne. This result fits predictions based on refugia in Assis et al. (2016, 2018), although results along this coastline are probably a function of Lough Hyne as a unique and protected habitat. This is not a likely explanation for the observed private alleles in this population, as the development of private alleles requires long term stability of large populations, at temporal scales longer than conservation status of Lough Hyne. Overall, we found high genotypic diversity as is expected in sexually reproducing kelps and the power of these microsatellites to discriminate among individuals within sites was high, as in Robuchon et al., (2014).

Genetic diversity Allelic richness and expected heterozygosity were very high in Lough Hyne $(8.17 ; 0.706)$. These values are greater than those from the Parc naturel marin d'Iroise, a marine protected area in Brittany, France, where the greatest $\mathrm{A}_{\mathrm{E}}$ was 5.2 (also based on a sample size of 19 diploid individuals as in our study so these values are comparable as the sampling effort was 
the same when using rarefaction) and $\mathrm{H}_{\mathrm{E}}$ was 0.622 (Robuchon et al., 2014). The shorelines of Brittany were considered as a genetic hotspot corresponding to a refugium during the LGM (Waltari \& Hickerson, 2013; Neiva et al. 2016). Evankow et al. (2019) found a maximum $A_{E}$ of $\sim 3$ and $\mathrm{H}_{\mathrm{E}}$ of $\sim 0.6$ in the Barents Sea in northern Norway. The values in Norway could be attributable to past glacial refugia or a consequence of the inclusion of the subspecies of $L$. hyperborea in this region, the cape form L. hyperborea f. cucullata P. Svensden \& J.M. Kain (Kain \& Jones, 1969; Svendsen \& Kain, 1971). The highest values of genetic diversity observed in our study in Lough Hyne in southern Ireland may also reflect patterns of past glaciation in the Celtic Sea (Waltari \& Hickerson, 2013; Neiva et al., 2016) or the potential for the cape form of L. hyperborea to exist in Irish sea loughs (Connor et al., 2004). Similar results in the congeneric L. digitata have been found, in which Irish populations have higher allelic diversity than Brittany (Neiva et al., submitted), suggesting a major role of this Irish refugium in post glacial recolonization.

Laminaria hyperborea in Lough Hyne also had high private allelic richness $\left(P_{a}=4.48\right)$, whilst all other sites had $\sim 0$ private alleles, based on a sample size of 19 diploid individuals. While Robuchon et al. (2014) found six private alleles in a site in St. Malo Bay (La Bigne), this was not based on rarefaction, but rather raw allelic counts as implemented in GenAlEx (Peakall \& Smouse, 2006, 2012). Re-analysing their data using HP-Rare (Kalinowski, 2005), the average private allelic richness throughout the sites surveyed in north western France in Robuchon et al. (2014) ranged from 0 to 0.2 , over $20 \times$ less than in Lough Hyne.

Climatic refugia potentially harbour alleles, leading to population resilience. Therefore, Lough Hyne could be an important source of propagules to re-populate/maintain L. hyperborea populations around southern Ireland. In contrast to our study, Bell \& Okamura (2005) found the 
genetic diversity of Lough Hyne populations of $N$. lapillus (a direct-developing gastropod) was lower within the lough when compared with Atlantic populations in southwestern Ireland, southwestern Britain and north-western France. Thus, predictions based on refugia in Assis et al. (2016) may be more nuanced along this coastline, warranting further fine scale sampling, as Lough Hyne is a unique and protected habitat. A kelp population like that of Lough Hyne, which has a consistent tidal current but low exposure to the open ocean, may be in a 'goldilocks' habitat with intermediate disturbance levels (Connell \& Slatyer, 1977) as it had the greatest allelic richness and genetic diversity in our study. Because this specific site is within a proposed glacial refugium, the influence of disturbance on population diversity in subtidal habitats should be further investigated. It has been suggested that ecological separation may have a greater influence on population genetic structuring than geographical separation (Durrant et al., 2018). However, there is no evidence for divergent ecological roles across $L$. hyperborea forests in Ireland, suggesting geographical or oceanographic distance has a greater impact on genetic structuring in the sampled sites.

Overall, trends in diversity cannot be linked to wave or tidal energy via our collection methodology, but the Bridges of Ross has very low allelic richness and genetic diversity, which is contrary to previous studies which found lowest diversity in sheltered habitats (Evankow et al., 2019). The lowest genetic diversity estimates were found at Zetland Pier (ZET; $\left.A_{E}=2.52\right)$ in County Cork and the Bridges of Ross $\left(\mathrm{H}_{\mathrm{E}}=0.283\right)$ in County Clare. Zetland Pier, in Bantry Bay, is a unique location in the southwest due to be harvested for industrial purposes. The low observed genetic diversity may indicate these populations theoretically require less protection from a species adaptation point of view, but obvious issues arise when the ecosystems these kelp support are heavily disturbed. A greater sampling effort, currently underway (Schoenrock, Chan, 
O'Connor, Power, Golden, Krueger-Hadfield, unpublished data) could inform local conservation efforts. Higher diversity in County Galway relative to Counties Clare and Cork indicates that populations along large areas of coastline are heterogeneous in their genetic makeup. Ancestral, local environmental and dispersal characteristics all probably influence patterns of genetic diversity at this regional scale. Future investigations are necessary in order to resolve important factors that underlie patterning in unique alleles, heterozygosity and allelic richness, particularly why populations such as Zetland Pier and Bridges of Ross have lower diversity than other sites on the west coast of Ireland.

\section{Population structure and connectivity}

This study is one of the first to address gene flow on a finer scale. We found that $80 \mathrm{~km}$ was the smallest geographic distance at which significant genetic differentiation (IBD) was observed along Ireland's coast, between New Quay and Leitir Mealláin in County Galway. Distances of 20 km were not significantly different, between An Cheathrú Rua and Leitir Mealláin. At some point between 20 to $80 \mathrm{~km}$, dispersal between populations becomes restricted, reflecting the intrinsic low dispersal of kelp propagules, but also potential dispersal via tidal and oceanic currents over wide swaths of inappropriate habitat types (Billot et al., 2003; Alberto et al., 2011). Dispersal distances in seaweed populations are better explained by habitat features such as continuity and ocean transport rather than spatial distances, causing very contrasting differentiation patterns to occur at identical distances (e.g. Johansson et al., 2015; Buonomo et al., 2017). The strong similarity of L. hyperborea populations within, and discontinuity between, the four counties sampled was evident along the first axis of DAPC ( $\sim 5 \%$ of the overall genetic variation). 
Hydrodynamic forces along the west coast of Ireland are strongly influenced by storm events in the Atlantic Ocean, tidal flux and thermo- or pycnoclines unique to coastal regions. High salinity values contribute to strong vertical and horizontal density gradients in southern Ireland (Fernand et al., 2006), while low salinity pulses are seasonal-annual, driven by freshwater flux from the River Shannon delta in western Ireland (Fernand et al., 2006; Nolan \& Lyons, 2006). Fernand et al. (2006) suggest that the plume from the River Shannon forms a buoyant freshwater current northward through Galway Bay, the velocity of which is regulated by wind, which could influence the connectivity between Clare and Galway sites. Thermal stratification is established in this region during the summer, from June to September (Fernand $e t$ al., 2006) when upper ocean temperatures can reach $18^{\circ} \mathrm{C}$, but kelp forest connectivity is likely to be most influenced by local features influencing transport, including exposure (i.e., wave energy; Graham et al., 1997), bathymetry and tides.

The northern sites in this study, from St. John's Point (SJP), County Donegal, to Leitir Mealláin and An Cheathrú Rua, County Galway, are south facing (Fig.1), exposed primarily to SSW-WNW swell and wind forces. The site in County Donegal contains the northernmost and the most geographically isolated population. This population was genetically differentiated from the others and dominated by a unique genetic cluster, suggesting reduced gene flow between the north and west counties which should be validated by further sampling in the north of Ireland. The three sites in Co. Galway were also dominated by one major genetic cluster, but admixture was apparent with genetic clusters that dominated the populations in Counties Clare and Cork. Both kelp forests in County Clare (Bridges of Ross and Newfy; Fig. 1) are north facing, impacted by swell and wind from the WSW-N, and heavy sedimentation with current-swept and turbulent flow regimes from the Shannon estuary (Bell et al., 2002), making them the most 
exposed sites in this study, which could contribute to isolation and reduced genetic diversity. Bridges of Ross had particularly low genetic diversity, which may be a result of its remote location on the Loop Head Peninsula. Environmental variations due to local conditions may produce 'ecotypes' within species, which could drive high genetic differentiation between populations. On the border of Counties Galway and Clare, the kelp forest in New Quay lies in a broad tidal inlet called the Doorus Straight (Fig. 1), which experiences high flow throughout the day as Cuan Chinn Mhara Bay fills or empties with the tides. Likewise, the kelp forest in 'the rapids' at Lough Hyne experience high flow throughout the day as the tide ebbs and floods, though this channel is narrower and shallower than the Doorus Straight $(1 \mathrm{~m}$ vs. $5 \mathrm{~m}$ depth at low tide). Zetland Pier and Lough Hyne in County Cork are also south facing (Fig. 1); however, the structure of Bantry Bay and Barloge Creek provide some protection from most south-westerly wind and swell.

Brennan et al. (2014) highlighted the potential for long-distance dispersal (several $\mathrm{km}$ ) in the congeneric L. digitata using a particle-tracking model in Strangford Lough, Northern Ireland, which experiences high tidal flow. Long-distance dispersal has also been hypothesized for $L$. ochroleuca, the southern European kelp species, which is reported to occur by entanglement with floating rafts, or as epiphytic gametophytes, as opposed to spore dispersal (Assis et al., 2018). Indeed, L. ochroleuca has recently been found in an isolated site in County Mayo, which could be due to boat traffic or such rafting with other taxa (Schoenrock et al., 2019). The 'kelp conveyor hypothesis' (Saunders, 2014) explains genetic connectivity between California and British Columbia via the winter Davidson Current in the buoyant kelps $M$. pyrifera and Nereocystis luetkeana (K. Mertens) Postels \& Ruprecht, and this could explain dispersal if the negatively buoyant Laminaria spp. of Europe hitchhiked on floating species/substrata. This 
certainly seems to be the best explanation underlying e.g. the colonization of offshore islands such as Orkneys, Faroes, and Iceland. If so, local and regional hydrodynamic forces driving oceanographic currents along Irish shores and beyond would have an impact on dispersal and population connectivity.

\section{Mating system}

The evidence of repeated genotypes, supported by $P_{s e x}$, at An Cheathrú Rua in two sporophytes and at St. John's Point in three sporophytes is not due to repeated sampling of individuals. Oppliger et al. (2014) found evidence of automixis, with diploid gametophytes being produced by the L. digitata sporophytes in Quiberon, an isolated site in Southern Brittany. However, the reproductive mode was overwhelmingly sexual based on population genetic analysis and they determined that the pattern of geographic parthenogenesis in this population was a maladaptation to its isolation. Robuchon et al. (2004) also found repeated genotypes in L. hyperborea but did not compute $P_{\text {sex }}$, suggesting that they might also have had some genotypes that were repeated and originated from the same sexual event. In our study neither population at An Cheathrú Rua or St. John's Point had low genetic diversity, which suggests that the repeated genotypes were not due to poor resolution based on the microsatellites used. Moreover, the lack of homozygote or heterozygote excess and linkage disequilibrium suggests regular sexual reproduction. Further sampling in these sites is necessary to determine the cause of repeated genotypes.

At Lough Hyne and New Quay, we found evidence of homozygote excess. Positive $F_{I S}$ values may be driven by null alleles, inbreeding, or population substructure. Ewers-Saucedo et al. (2016) demonstrated evidence of large variance in reproductive success driving homozygote excess as well. Although we found evidence of null alleles, they are probably not the main cause 
of homozygote excess, especially at New Quay in which few loci had evidence of null alleles (Supplementary table 3). There was evidence of null alleles at Lough Hyne at each locus ranging from 0.042 to 0.160 , indicating that null alleles may have inflated the number of homozygotes at this site.

However, selfing can occur in dioicious taxa, such as kelps, when gamete unions occur between sibling gametophytes that share the same diploid, sporophytic parent (Klekowski, 1969), but the occurrence and evolution of inter-gametophytic selfing has not been thoroughly addressed in macroalgae, particularly in kelps (reviewed in Krueger-Hadfield, 2019). Selffertilization and inbreeding may be favoured by kelp species with limited dispersal since reproduction may involve preferentially spatially close and potential sibling neighbours (Coyer et al., 1997; Raimondi et al., 2004). Theoretically, this mode of reproduction comes with a cost, such as reduced fitness through inbreeding depression (Raimondi et al., 2004; but see Barner et al., 2011). However, many low-dispersal seaweeds exhibit patchy distributions exceeding the range of propagule dispersal (e.g. estuarine species, species restricted to infrequent sheltered micro-sites within otherwise exposed shores, species in sea loughs), implying good capacity to cope with high levels of inbreeding. Kelp populations may need little gene flow to maintain diversity. Reef populations of non-native Undaria pinnatifida in France are self-sustaining after initial colonization, needing little input from marinas or farms to continue colonizing the habitat, yet showing no sign of local adaptation after 20-40 generations (Guzinski et al., 2018). Competition between selfing and outcrossed individuals exacerbates the effects of inbreeding depression, specifically during the diploid phase, diminishing the number of self-fertilized juvenile individuals and their ability to survive, but potentially maintaining genetic diversity as outcrossed individuals persist in the population (Raimondi et al., 2004). Bell \& Okamura (2005) 
found evidence of inbreeding in Lough Hyne in the gastropod Nucella lapillus that lead to a reduction in genetic diversity. While this might be the case at New Quay, which did have lower genetic diversity than the two other Co. Galway sites, there are probably other factors contributing to the homozygote excess at Lough Hyne.

Population substructure (i.e., Wahlund effect) also artificially inflates homozygosity. The evidence of not only excess homozygosity, but also significant linkage disequilibrium at Lough Hyne hints at our sampling of two genetic pools within the lough. Hierarchical sampling is necessary in order to tease apart the relative influence of the mating system versus population sub structuring (see as an example Krueger-Hadfield et al., 2013). Two genetic pools might also explain the high levels of genetic diversity we find at this site, which curiously contradicts the patterns found in N. lapillus in Bell \& Okamura (2005). We have not compared L. hyperborea populations from sites near the opening of Lough Hyne to the Atlantic, something that is critical to understand connectivity and the genetic consequences of the isolation imposed on the Lough Hyne population due to topographical and geological factors.

\section{Future research and knowledge gaps}

Kelp forests are essential ecosystem engineers structuring subtidal habitats not only on the west coast of Ireland, but worldwide (Dayton, 1985). Large scale studies are necessary due to the dynamic threats kelp forest ecosystems face, such as ocean warming, competition with faster growing, non-native species and over harvesting (Wernberg et al., 2019). However, one impediment to large-scale multi-lab genotyping projects is the calibration of alleles across sequencing platforms. In addition to characterizing the genetic diversity of Irish L. hyperborea, we also performed a calibration across the capillary sequencers at UAB, SBR, and CCMAR. 
Microsatellite binning can be somewhat arbitrary and thus prone to problems when combining data sets across labs. However, here we provide a conversion for use in future studies of $L$. hyperborea and possibly other Laminaria species. We used previous allele calls from Robuchon et al. (2014) and our data can be combined with their data set available on Dryad. For example, using the loci common to both our studies, we analysed genetic structure in Ireland compared with northwestern France from Robuchon et al. (2014) using DAPC as described above. We found that not only are Irish sites genetically distinct from French sites (separation along the first principal components axis), but L. hyperborea populations along the Irish coast had much stronger genetic structure, as evidenced by greater separation of the ellipses of the four Irish counties along the second principal components axis compared with the tight clustering of the French regions of St. Malo, Morlaix Bay, Iroise Sea and Southern Brittany (Fig. 6). We could not compare to Norwegian sites as we did not have access to the raw allele calls from Evankow et al. (2019), but it should be possible to combine their data should raw alleles be made available, using our conversion in Supplementary table S2. This is a first step to better integrating studies of genetic diversity across labs using the same genetic markers.

The scope of this research should be extended to more kelp populations in the North Atlantic, particularly Ireland where population structure is nuanced and coastline dependent. There are clear differences in genetic structure in Ireland (our study) compared with France (Robuchon et al., 2014) and we can directly compare these through microsatellite calibrations in this study. Direct comparisons with Norwegian populations studied by Evankow et al. (2019) and across L. hyperborea's range in Europe would validate the Assis et al. (2016) model for glacial refugia, and facilitate regional conservation alongside local efforts. Studies should utilize a nested sampling design (across regions) to provide greater insight into dispersal potential, gene 
flow and the role of local hydrodynamic forces in population dynamics of these important ecosystem engineers.

\section{ACKNOWLEDGEMENTS}

We would like to thank the following divers from NUIGSAC and Seasearch Ireland, Sam Afoullouss, Thomas Rossiter, Tony O'Callaghan, and Dr Rob McAllen from UCC. We also thank Caitlin Cox of the Heflin Center for Genomic Sciences for use of the capillary sequencer, and Maggie Amsler for help with freeze drying samples. We thank the Biogenouest Genomics core facility at SBR for its technical support. This project was funded by the Irish Research Council Government Postdoctoral Fellowship GOPID/2016/545 ("Closing the knowledge gap on Irish kelp forest ecology"), ASSEMBLEplus transnational access ("'Genetic Diversity of Irish Kelp (Laminaria hyperborea) from a European View (KeUVie; 6886)") to Centro de Ciências do Mar, the Marine Institute Networking Initiative, and Environmental Protection Agency 2018W-MS-35 ("KelpRes: The diversity and resilience of kelp ecosystems in Ireland") to KMS; British Phycological Society Studentship to AMOC; start-up funds from the University of Alabama at Birmingham to SAKH; Portuguese national funds from FCT - Foundation for Science and Technology grants UID/Multi/04326/2019, GENEKELP PTDC/MAR-

EST/6053/2014, SFRH/BPD/88935/2012 (DL 57/2016/CP1361/CT0010) and

SFRH/BSAB/150485/2019, and a Pew Marine Fellowship to EAS. MARFOR Biodiversa/0004/2015 to MV and EAS.

\section{Supplementary Information}


The following supplementary material is accessible via the Supplementary Content tab on the article's online page at http://xxx

Supplementary table 1 . The number of alleles, allele range, null allele frequency, and TANDEM ver. 1.09 output (Matschiner \& Saltzburger 2009), including the specified repeat size, rounding method, average rounding error and error threshold for each microsatellite locus used to genotype L. hyperborea populations.

Supplementary table 2. The conversion of alleles from the raw data obtained from the capillary sequencer at the University of Alabama at Birmingham (UAB), the Station Biologique de Roscoff (SBR), and the Universidad Do Algarve (CCMAR).

Supplementary table 3. The null allele frequencies per population and per locus as calculated using ML-NullFreq (Kalinowski 2006) with 1000 randomizations.

Supplementary table 4. The sample ID, the multilocus genotype (MLG) number for each sample, the pgen value (probability of a genotype under Hardy-Weinberg assumptions), psex (the probability that repeated genotypes originate from distinct sexual events (i.e., being from different genets and not ramets of the same MLG), and the psex p-value (psex p-values $<0.05$ would be considered as ramets of the same genet whereas p-values $>0.05$ are considered to be separate genets). 
Supplementary table 5. Single locus genetic and genotypic diversity estimates for L. hyperborea based on 9 microsatellite loci.

Supplementary table 6. a) Genetic differentiation as measure by allele identity (FST) and the geographic distance for all pairwise population comparisons above the diagonal. Significant FST are shown in bold. B) FST / (1-FST) is given below the diagonal.

Supplementary fig. 1. Discriminant analyses of principal components (DAPC).

Supplementary fig. 2. a) The DIC scores \pm the standard error of the mean for $K=2$ to $K=10$ using instruct.

\section{AUTHOR CONTRIBUTIONS}

K. M. Schoenrock conceived the project and experimental design, collected tissue in the field, performed fragment analysis for conversions across sequencing platforms, wrote and edited the manuscript, and wrote the supporting grants for this research. S. A. Krueger-Hadfield conceived the project and experimental design, performed bench work, performed fragment analysis, analysed data, performed fragment analysis for conversions across sequencing platforms, wrote and edited the manuscript, and wrote the supporting grants for this research. A. M. O'Connor collected tissue in the field, performed bench work, and wrote and edited the manuscript. J. Neiva and S. Mauger performed fragment analysis for conversions across sequencing platforms and edited the manuscript. E. Á. Serrão and M. Valero edited the manuscript, discussed results, and funded the genotyping at CCMAR at Roscoff. 


\section{DATA ACCESSIBILITY}

All data is freely available online: doi:10.5061/dryad.44j0zpc9g 


\section{REFERENCES}

Agapow, P.-M. \& Burt, A. (2001). Indices of multilocus linkage disequilibrium. Molecular Ecology Notes, 1: 101-2.

Alberto, F., Raimondi, P.T., Reed, D.C., Watson, J.R., Siegel, D.A., Mitarai, S., Coelho, N. \& Serrão, E. Á. (2011). Isolation by oceanographic distance explains genetic structure for Macrocystis pyrifera in the Santa Barbara Channel. Molecular Ecology, 20: 2543-2554.

Amsler, C.D., Reed, D.C. \& Neushul, M. (1992). The microclimate inhabited by macroalgal propagules. British Phycological Journal, 27: 253-270.

Araujo, R.M., Assis, J., Aguillar, R., Airoldi, L., Barbara, I., Bartsch, I., Bekkby, T., Christie, H., Davoult, D., Derrien-Courtel, S., Fernandez, C., Fredriksen, S., Gevaert, F., Gundersen, H., Le Gal, A., Leveque, L., Mieszkowska, N., Norderhaug, K. M., Oliveira, P., Puente, A., Rico, J. M., Rinde, E., Schubert, H., Strain, E. M., Valero, M., Viard, F. \& Sousa-Pinto, I. (2016). Status, trends and drivers of kelp forests in Europe: an expert assessment.

Biodiversity and Conservation, 25: 1319-1348.

Assis, J., Lucas, A.V., Bárbara, I. \& Serrão, E.Á. (2016). Future climate change is predicted to shift long-term persistence zones in the cold-temperate kelp Laminaria hyperborea. Marine Environmental Research, 113: 174-182.

Assis, J., Serrão, E.Á., Coelho, N.C., Tempera, F., Valero, M. \& Alberto, F. (2018). Past climate changes and strong oceanographic barriers structured low-latitude genetic relics for the golden kelp Laminaria ochroleuca. Journalof Biogeography, 45: 2326-2336.

Assis, J., Berecibar, E., Claro, B., Alberto, F., Reed, D., Raimondi, P. \& Serrão, E. Á . (2017). Major shifts at the range edge of marine forests: the combined effects of climate changes and limited dispersal. Scientific Reports, 7: 44348. https://doi.org/10.1038/srep44348 
Assis, J., Coelho, N.C., Lamy, T., Valero, M., Alberto, F. \& Serrão, E.Á. (2016). Deep reefs are climatic refugia for genetic diversity of marine forests. Journal of Biogeography, 43: 833844.

Bailleul, D., Stoeckel, S. \& Arnaud-Haond, S. (2016). RClone: a package to identify MultiLocus Clonal Lineages and handle clonal data sets in R . Methods in Ecology and Evolution, 7: 966-970.

Barbier, E.B., Koch, E.W., Silliman, B.R., Hacker, S.D., Wolanski, E., Primavera, J., Granek, E.F., Polasky, S., Aswani, S., Cramer, L.A., Stoms, D.M., Kennedy, C.J., Bael, D., Kappel, C.V., Perillo, G.M.E. \& Reed, D.J. (2008). Coastal ecosystem-based management with nonlinear in ecological functions and values. Science, 319: 321-323.

Barner, A.K., Pfister, C.A. \& Wootton, J.T. (2011). The mixed mating system of the sea palm kelp Postelsia palmaeformis: few costs to selfing. Proceeding of the Royal Society B: Biological Sciences, 278:1347-1355.

Bell, J., Barnes, D. \& Turner, J. (2002). The importance of micro and macro morphological variation in the adaptation of a sublittoral demosponge to current extremes. Marine Biology, 140: $75-81$.

Bell, J.J. \& Okamura, B. (2005). Low genetic diversity in a marine nature reserve: re-evaluating diversity criteria in reserve design. Proceedings of the Royal Society B, 272: 1067-1074.

Billot, C., Rousvoal, S., Estoup, A., Epplen, J.T., Saumitou-Laparade, P., Valero, M. \& Kloareg, B. (2018). Isolation and characterization of microsatellite markers in the nuclear genome of the brown alga Laminaria digitata (Phaeophyceae). Molecular Ecology, 7: 1778-1780.

Billot, C., Engel, C., Rousvoal, S., Kloareg, B. \& Valero, M. (2003). Current patterns, habitat discontinuities and population genetic structure: the case of the kelp Laminaria digitata in 
the English Channel. Marine Ecology Progress Services, 253: 111-121.

Buonomo, R., Assis, J., Fernandes, F., Engelen, A.H., Airoldi, L. \& Serrão, E.Á. (2017). Habitat continuity and stepping-stone oceanographic distances explain population genetic connectivity of the brown alga Cystoseira amentacea. Molecular Ecology, 26: 766780.Burrows, M.T., Harvey, R. \& Robb, L. (2008). Wave exposure indices from digital coastlines and the prediction of rocky shore community structure. Marine Ecology Progress Series, 353: 1-12.

Bustamante, R.H. \& Branch, G.M. (1996). The dependence of intertidal consumers on kelpderived organic matter on the west coast of South Africa. Journal of Experimental Marine Biology and Ecology, 196: 1-28.

Coelho, N.C., Serrão, E.Á. \& Alberto, F. (2014). Characterization of fifteen microsatellite markers for the kelp Laminaria ochroleuca and cross species amplification within the genus. Microsatellite Letters, 6: 949-950.

Collins, C.J., Fraser, C.I., Ashcroft, A. \& Waters, J.M. (2010). Asymmetric dispersal of southern bull-kelp (Durvillaea antarctica) adults in coastal New Zealand: testing an oceanographic hypothesis. Molecular Ecology, 19: 4572-4580.

Connell, J.H. \& Slatyer, R.O. (1977). Mechanisms of succession in natural communities and their role in community stability and organization. American Naturalist, 111: 1119-1144.

Connor, D.W., Allen, J.H., Golding, N., Howell, K.L., Lieberknecht, L.M., Northen, K.O. \& Reker, J.B. (2004). The Marine Habitat Classification for Britain and Ireland. Version 04.05. ISBN 186107561 8. In JNCC (2015), The Marine Habitat Classification for Britain and Ireland Version 15.03. [2019-12-07]. Joint Nature Conservation Committee, Peterborough. Available from https://mhc.jncc.gov.uk/ 
Couceiro, L., Robuchon, M., Destombe, C. \& Valero, M. (2012). Management and conservation of the kelp species Laminaria digitata: using genetic tools to explore the potential exporting role of the MPA "Parc naturel marin d'Iroise". Aquatic Living Resources, 26: 197-205.

Coyer, J.A., Olsen, J.L. \& Stam, W.T. (1997). Genetic variability and spatial separation in the Sea Palm kelp Postelsia palmaeformis (Phaeophyceae) as assessed with M13 fingerprints and RAPDS1. Journal of Phycology, 33: 561-568.

Dayton, P.K. (1985). Ecology of Kelp Communities. Annual Review of Ecology, Evolution, and Systematics, 16: 215-245.

de Bettignies, F., Dauby, P., Thomas, F., Gobet, A., Delage, L., Bonher, O., Loisel, S. \& Davoult, D. (in revision). Degradation dynamics and processes within kelp fragments accumulations: an in situ experimental approach. Journal of Phycology.

Denny, M.W. (1988). Biology and the Mechanics of the Wave-Swept Environment. Princeton University Press, Princeton.

Dorken, M.E. \& Eckert, C.G. (2001). Severely reduced sexual reproduction in northern populations of a clonal plant, Decodon verticillatus (Lythraceae). Journal of Ecology, 89: $339-350$.

Durrant, H., Barrett, N., Edgar, G., Coleman, M. \& Burridge, C. (2018). Seascape habitat patchiness and hydrodynamics explain genetic structuring of kelp populations. Marine Ecology Progress Series, 587: 81-92.

Estes, J.A. \& Duggins, D.O. (1995). Sea Otters and Kelp Forests in Alaska : Generality and Variation in a Community Ecological Paradigm. Ecological Monographs, 65: 75-100.

Evankow, A., Christie, H., Hancke, K., Brysting, A.K., Junge, C., Fredriksen, S. \& Thaulow, J. (2019). Genetic heterogeneity of two bioeconomically important kelp species along the 
Norwegian coast. Conservation Genetics, 20: 1-14.

Ewers-Saucedo, C., Zardus, J.D. \& Wares, J.P. (2016). Microsatellite loci discovery from nextgeneration sequencing data and loci characterization in the epizoic barnacle Chelonibia testudinaria (Linnaeus, 1758). PeerJ, 4. DOI: 10.7717/peerj.2019

Fernand, L., Nolan, G.D., Raine, R., Chambers, C.E., Dye, S.R., White, M. \& Brown, J. (2006). The Irish coastal current: A seasonal jet-like circulation. Continental Shelf Research, 26: $1775-1793$.

Filbee-Dexter, K. \& Wernberg, T. (2018). Rise of Turfs: A New Battlefront for Globally Declining Kelp Forests. Bioscience,. 68: 64-76.

Filbee-Dexter, K., Wernberg, T., Norehaug, K.M., Ramirez-Llodra, E. \& Pedersen, M.F. (2018). Movement of Pulsed Resource Subsidies from kelp forests to deep fjords. Oecologia, 187: 291-304.

Fredriksen, S., Sjøtun, K., Lein, T.E. \& Rueness, J. (1995). Spore dispersal in Laminaria hyperborea (Laminariales, Phaeophyceae). Sarsia, 80: 47-54.

Gao, H., Williamson, S. \& Bustamante, C.D. (2007). An MCMC Approach for Joint Inference of Population Structure and Inbreeding Rates from Multi-Locus Genotype Data. Genetics, 176: $1635-1651$.

Goudet, J. (1995). Computer note. SPAM (version 3.2): statistics program for analyzing mixtures. Journal of Heredity, 86: 485-486.

Graham, M.H. (2004). Effects of local deforestation on the diversity and structure of southern California giant kelp forest food webs. Ecosystems, 7: 341-357.

Graham, M.H., Harrold, C., Lisin, S., Light, K., Watanabe, J.M. \& Foster, M.S. (1997). Population dynamics of giant kelp Macrocystis pyrifera along a wave exposure gradient. 
Marine Ecology Progress Series, 148: 269-279.

Guzinski, J., Ballenghien, M., Laurent, C.D. \& Viard, L.F. (2018). Population genomics of the introduced and cultivated Pacific kelp Undaria pinnatifida: Marinas — not farms — drive regional connectivity and establishment in natural rocky reefs. Evolutionary Applications, 11: $1582-1597$.

Guzinski, J., Mauger, S., Cock, J.M. \& Valero, M. (2016). Characterization of newly developed expressed sequence tag-derived microsatellite markers revealed low genetic diversity within and low connectivity between European Saccharina latissima populations. Journal of Applied Phycology, 28: 3057-3070.

Haffer, J. (1982). General aspects of the refuge theory. In Biological Diversification in the Tropics (Prance, G., editor), 6-24. Columbia University Press, New York..

Hoelzel, A.R., Fleischer, R.C., Campagna, C., Le Boeuf, B.J. \& Alvord, G. (2002). Impact of population bottleneck on symmetry and genetic diversity in the northern elephant seal. Journal of Evolutionary Biology, 15: 567-575.

Jakobsson, M. \& Rosenberg, N.A. (2007). CLUMPP: a cluster matching and permutation program for dealing with label switching and multimodality in analysis of population structure. Bioinformatics, 23: 1801-1806.

Johansson, M.L., Alberto, F., Reed, D.C., Raimondi, P.T., Coelho, N.C., Young, M.A., Drake, P.T., Edwards, C.A., Cavanaugh, K., Assis, J., Ladah, L.B., Bell, T.W., Coyer, J.A., Siegel, D.A. \& Serrão, E.Á. (2015). Seascape drivers of Macrocystis pyrifera population genetic structure in the northeast Pacific. Molecular Ecology, 24: 4866-4885 .John, D.M. (1969). An Ecological Study on Laminaria ochroleuca. Journal of the Marine Biological Association of the United Kingdom, 49: 175-187. 
Jombart, T. (2008). Adegenet: a R package for the multivariate analysis of genetic markers. Bioinformatics, 24: 1403-1405.

Jombart, T. \& Ahmed, I. (2011). Adegenet 1.3-1: new tools for the analysis of genome-wide SNP data. Bioinformatics, 27: 3070-3071.

Jombart, T., Devillard, S. \& Balloux, F. (2010). Discriminant analysis of principal components: a new method for the analysis of genetically structured populations. BMC GenetIcs, 11: 94.

Jombart, T., Pontier, D. \& Dufour, A.-B. (2009). Genetic markers in the playground of multivariate analysis. Heredity, 102: 330-341.

Kaehler, S., Pakhomov, E.A., Kalin, R.M. \& Davis, S. (2006). Trophic importance of kelpderived suspended particulate matter in a through-flow sub-Antarctic system. Marine Ecology Progress Series, 316: 17-22.

Kain, J.M. (1976). The biology of Laminaria hyperborea VIII. Growth on cleared areas. Journal of the Marine Biological Association of the United Kingdom, 56: 267-290.

Kain, J.M. (1979). A view of the Genus Laminaria. Oceanography and Marine Biology Annual Review, 17: 101-161.

Kain, J.M. \& Jones, M.N.S. (1969). The Biology of Laminaria hyperborea. V. Comparison with early stages of competitors. Journal of the Marine Biological Association of the United Kingdom, 49: 455.

Kain, J.M. \& Jones, N.S. (1964). Aspects of the Biology of Laminaria hyperborea III. Survival and Growth of Gametophytes. Journal of the Marine Biological Association of the United Kingdom, 44: 415-453.

Kalinowski, S.T. (2005). hp-rare 1.0: a computer program for performing rarefaction on measures of allelic richness. Molecular Ecology Notes, 5: 187-189. 
Kalinowski, S.T. \& Taper, M.L. (2006). Maximum likelihood estimation of the frequency of null alleles at microsatellite loci. Conservation Genetics, 7: 991-995.

Kamvar, Z.N., Brooks, J.C. \& Grünwald, N.J. (2015). Novel R tools for analysis of genomewide population genetic data with emphasis on clonality. Frontiers in Genetics, 6: 208.

Kamvar, Z.N., Tabima, J.F. \& Grünwald, N.J. (2014). Poppr : an R package for genetic analysis of populations with clonal, partially clonal, and/or sexual reproduction. PeerJ, 2: e281.

Klekowski, E.J. (1969). Reproductive biology of the Pteridophyta. II Theoretical considerations. Botanical Journal of the Linnean Society, 62: 347-359.

Kopelman, N.M., Mayzel, J., Jakobsson, M., Rosenberg, N.A. \& Mayrose, I. (2015). Clumpak : a program for identifying clustering modes and packaging population structure inferences across K. Molecular Ecology Resources, 15: 1179-1191.

Krueger-Hadfield, S.A. (in press) What's ploidy got to do with it? Understanding the evolutioanry ecology of macroalgal invasions necessitates incorporating life cycle complexity. Evolutionary Applications, doi:10.1111/eva.12843.

Krueger-Hadfield, S.A., Kollars, N.M., Byers, J.E., Greig, T.W., Hammann, M., Murray, D.C., Murren, C.J., Strand, A.E., Terada, R., Weinberger, F. \& Sotka, E.E. (2016). Invasion of novel habitats uncouples haplo-diplontic life cycles. Molecular Ecology, 25: 3801-3816.

Krueger-Hadfield, S.A., Kollars, N.M., Strand, A.E., Byers, J.E., Shainker, S.J., Terada, R., Greig, T.W. Hammann, M., Murray, D.C., Weinberger, F. \& Sotka, E.E. (2017). Genetic identification of source and likely vector of a widespread marine invader. Ecology and Evolution, 7: 4432-4447.

Krueger-Hadfield, S.A., Roze, D., Mauger, S. \& Valero, M. (2013). Intergametophytic selfing and microgeographic genetic structure shape populations of the intertidal red seaweed 
Chondrus crispus. Molecular Ecology, 22: 3242-3260.

Krumhansl, K.A., Okamoto, D.K., Rassweiler, A., Novak, M., Bolton, J.J., Cavanaugh, K.C., Connell, S.D. Johnson, C.R., Konar, B., Ling, S.D., Micheli, F., Norderhaug, K.M., PérezMatus, A., Sousa-Pinto, I., Reed, D.C., Salomon, A.K., Shears, N.T., Wernberg, T., Anderson, R.J., Barrett, N.S., Buschmann, A.H., Carr, M.H., Caselle, J.E., Derrien-Courtel, S., Edgar, G.J., Edwards, M., Estes, J.A., Goodwin, C., Kenner, M.C., Kushner, D.J., Moy, F.E., Nunn, J., Steneck, R.S., Vásquez, J., Watson Cc, J., Witman, J.D. \& Byrnes, J.E.K. (2016). Global patterns of kelp forest change over the past half-century. Proceedings of the National Academy of Sciences of the USA, 113: 13785-13790.

Krumhansl, K.A. \& Scheibling, R.E. (2012). Production and fate of kelp detritus. Marine Ecology Progress Series, 467: 281-302.

Leclerc, J.C., Riera, P., Laurans, M., Leroux, C., Lévêque, L. \& Davoult, D. (2015). Community, trophic structure and functioning in two contrasting Laminaria hyperborea forests. Estuarine and Coastal Shelf Science, 152: 11-22.

Lorentsen, S.H., Sjøtun, K. \& Grémillet, D. (2010). Multi-trophic consequences of kelp harvest. Biological Conservation, 143: 2054-2062.

Mac Monagail, M., Cummins, E., Bermejo, R., Daly, E., Costello, D. \& Morrison, L. (2018). Quantification and feed to food transfer of total and inorganic arsenic from a commercial seaweed feed. Environment International, 118: 314-324.

Matschiner, M. \& Salzburger, W. (2009). TANDEM: integrating automated allele binning into genetics and genomics workflows. Bioinformatics, 25: 1982-1983.

Meirmans, P.G. \& van Tienderen, P.H. (2004). genotype and genodive: two programs for the analysis of genetic diversity of asexual organisms. Molecular Ecology Notes, 4: 792-794. 
Mineur, F., Arenas, F., Assis, J., Davies, A.J., Engelen, A.H., Fernandes, F., Malta, E., Thibaut, T., Van Nguyen, T., Vaz-Pinto, F. \& Vranken, S. (2015). European seaweeds under pressure: Consequences for communities and ecosystem functioning. Journal of Sea Research, 98: 91-108.

Neiva, J., Paulino, C., Nielsen, M.M., Krause-Jensen, D., Saunders, G.W., Assis, J., Bárbara, I., Tamigneaux, E., Gouveia, L., Aires, T., Marbà, N., Bruhn, A., Pearson, G.A. \& Serrão, E.Á . (2018). Glacial vicariance drives phylogeographic diversification in the amphi-boreal kelp Saccharina latissima. Scientific Reports, 8: 1112. https://doi.org/10.1038/s41598-018-

\section{$\underline{19620-7}$}

Nolan, G.D. \& Lyons, K. (2006). Ocean climate variability on the western Irish Shelf, an emerging time series. In ICES CM/C:28 Theme Session C.

Norton, T.A. (1992). Dispersal by macroalgae. British Phycology Journal, 27: 293-301.

Olsen, J.L., Zechman, F.W., Hoarau, G., Coyer, J.A., Stam, W.T., Valero, M. \& Åberg, P. (2010). The phylogeographic architecture of the fucoid seaweed Ascophyllum nodosum: an intertidal 'marine tree' and surviviro of more than one glacial-interglacial cycle. Journal of Biogeography, 37: 842-856.

Peakall, R. \& Smouse, P.E. (2006). Genalex 6: genetic analysis in Excel. Population genetic software for teaching and research. Molecular Ecology Notes, 6: 288-95.

Peakall, R. \& Smouse, P.E. (2012). GelAlEx 6.5: genetic analysis in Excel. Population genetic software for teaching and research-an update. Bioinformatics, 28: 2537-2539.

Pessarrodona, A., Moore, P.J., Sayer, M.D.J. \& Smale, D.A. (2018). Carbon assimilation and transfer through kelp forests in the NE Atlantic is diminished under a warmer ocean climate. Global Change Biology, 24: 4386-4398. 
R Core, T. (2018). R: a Language and Environment for Statistical Computing. R foundation for statistical computing, Vienna, Austria.

Raimondi, P.T., Reed, D.C., Gaylord, B. \& Washburn, L. (2004). Effects of Self-Fertilization in the Giant Kelp, Macrocystis pyrifera. Ecology, 85: 3267-3276.

Robuchon, M., Le Gall, L., Mauger, S. \& Valero, M. (2014). Contrasting genetic diversity patterns in two sister kelp species co-distributed along the coast of Brittany, France. Molecular Ecology, 23: 2669-2685.

Rousset, F. (1997). Genetic Differentiation and Estimation of Gene Flow from FStatistics Under Isolation by Distance. Genetics, 147: 1219-1228.

Ruz, C.S., Muth, A.F., Tala, F. \& Pérez-Matus, A. (2018). The herbivorous fish, Aplodactylus punctatus, as a potential facilitator of dispersal of kelp, Lessonia trabeculata, in Chile. Journal of Experimental Marine Biology and Ecology, 500: 112-119.

Saunders, G.W. (2014). Long distance kelp rafting impacts seaweed biogeography in the Northeast Pacific: the kelp conveyor hypothesis. Journal of Phycology, 50: 968-974.

Schoenrock, K.M., O’Callaghan, T., O’Callaghan, R. \& Krueger-Hadfield, S.A. (2019). First record of non-native Laminaria ochroleuca Bachelot de la Pylaie in Ireland found in Béal an Mhuirthead, County Mayo. Marine Biodiversity Records, 12: 9.

Sheppard, C.R.C., Jupp, B.P., Sheppard, A.L.S. \& Bellamy, D.J. (1978). Studies on the Growth of Laminaria hyperborea (Gunn.) Fosl. and Laminaria ochroleuca De La Pylaie on the French Channel Coast. Botanica Marina, 21: 109-116.

Simkanin, C., Power, A.M., Myers, A., McGrath, D., Southward, A., Mieszkowska, N., Leaper, R. \& O’Riordan, R. (2005). Using historical data to detect temporal changes in the abundances of intertidal species on Irish shores. Jouranl of the Marine Biological 
Association of the United Kingdom, 85: 1329-1340.

Sokal, R.R. \& Rohlf, F.J. (1995). Biometry: The Principles and Practice of Statistics in Biological Research. 3rd edition. W.H. Freeman and Co., New York.

Stevens, C.L., Hurd, C.L. \& Isachsen, P.E. (2003). Modelling of diffusion boundary-layers in subtidal macroalgal canopies: The response to waves and currents. Aquatatic Science, $\mathbf{6 5}$ : $81-91$.

Svendsen, P. \& Kain, J.M. (1971). The taxonomic status, distribution, and morphology of Laminaria cucullata Sunsu Jorde and Klavestad. Sarsia, 46: 1-22.

Teagle, H. \& Smale, D.A. (2018). Climate-driven substitution of habitat-forming species leads to reduced biodiversity within a temperate marine community. Diversity and Distributions, 24: $1367-1380$.

Toonen, R.J. \& Hughes, S. (2001). Increased throughput for fragment analysis on an ABI Prism® 377 automated sequencer using a membrane comb and STRand software. Biotechniques, 31: 1320-1325

Udy, J. (2019). Drivers of temperate reef fish community structure and food web architecture. University of Otago, $121 \mathrm{pp}$.

Valero, M., Guillemin, M.-L., Destome, C., Jacquemin, B., Gachon, C.M.M., Badis, Y., Buschmann, A.H., Camus, C. \& Faugeron, S. (2017). Perspectives on domestication research for sustainable seaweed aquaculture. Perspectives in Phycology, 4: 33-46.

Waltari, E. \& Hickerson, M.J. (2013). Late Pleistocene species distribution modelling of North Atlantic intertidal invertebrates. Journal of Biogeography, 40: 249-260.

Weir, B.S. \& Cockerham, C.C. (1984). Estimating F-statistics for the analysis of population structure. Evolution , 38: 1358-1370. 
Wernberg, T., Bennett, S., Babcock, R.C., De Bettignies, T., Cure, K., Depczynski, M., Dufois, F., Fromon, J., Fulton, C.J., Hovey, R.K, Harvey, E.S., Holmes T.H., Kendrick, G.A., Radford, B., Santana-Garcon, J., Saunders, B.J., Smale, D.A., Thomsen, M.S., Tuckett, C.A., Tuya, F., Vanderklift, M.A. \& Wilson, S. (2016). Climate-driven regime shift of a temperate marine ecosystem. Science, 353: 169-172

Wernberg, T., Krumhansl, K., Filbee-Dexter, K. \& Pedersen, M.F. (2019). Status and trends for the world's kelp forests. In World Seas: An Environmental Evaluation (Sheppard, C., editor), 57-78. Academic Press.

Wernberg, T., Russell, B.D., Moore, P.J., Ling, S.D., Smale, D.A., Campbell, A., Coleman, M.A., Steinberg, P.D., Kendrick, G.A. \& Connell, S.D. (2011). Impacts of climate change in a global hotspot for temperate marine biodiversity and ocean warming. Journal of Experimental Marine Biology and Ecology, 400: 7-16.

Yesson, C., Bush, L.E., Davies, A.J., Maggs, C.A. \& Brodie, J. (2015a). Large brown seaweeds of the British Isles: Evidence of changes in abundance over four decades. Estuarine and Coastal Shelf Science, 155: 167-175.

Yesson, C., Bush, L.E., Davies, A.J., Maggs, C.A. \& Brodie, J. (2015b). The distribution and environmental requirements of large brown seaweeds in the British Isles. Journal of the Marine Biological Associ United Kingdom, 95: 669-680. 


\section{TABLES}

Table 1. Coordinates (DMS), number genotyped (N), and depth (lowest astronomical tide) for kelp forest sites (with site code) where Laminaria hyperborea samples were collected in Ireland.

\begin{tabular}{lccccc}
\hline County & Site Name & Latitude & Longitude & Depth (m) & N \\
\hline Donegal & St. John's Point (SJP) & $54^{\circ} 34^{\prime} 42.17^{\prime \prime}$ & $8^{\circ} 26^{\prime} 06.58^{\prime \prime}$ & 6 & 19 \\
\hline Galway & *Leitir Mealláin (LMN) & $53^{\circ} 13^{\prime} 40.99^{\prime \prime}$ & $9^{\circ} 43^{\prime} 59.64^{\prime \prime}$ & 5 & 24 \\
& *An Cheathrú Rua & & & & \\
& (ACR) & $53^{\circ} 14^{\prime} 38.3^{\prime \prime}$ & $9^{\circ} 34^{\prime} 49.64^{\prime \prime}$ & 5 & 25 \\
& & & & \\
\hline Clare & New Quay (NEQ) & $53^{\circ} 09^{\prime} 23.18^{\prime \prime}$ & $9^{\circ} 04^{\prime} 27.9^{\prime \prime}$ & 4 & 26 \\
& *Newfy (NFY) & $52^{\circ} 40^{\prime} 58.41^{\prime \prime}$ & $9^{\circ} 39^{\prime} 35.05^{\prime \prime}$ & 5 & 25 \\
\hline Cork & Zetland Pier (ZET) & $51^{\circ} 41^{\prime} 40.06^{\prime \prime}$ & $9^{\circ} 35^{\prime} 40.35^{\prime \prime}$ & 4 & 22 \\
& Lough Hyne (HYN) & $51^{\circ} 29^{\prime} 58.6 "$ & $9^{\circ} 17^{\prime} 44.03 "$ & 2 & 26 \\
\hline
\end{tabular}

* indicates sites used for short-term ecological research by KMS. 
Table 2. Multilocus genetic and genotypic diversity estimates for Laminaria hyperborea based on nine microsatellite loci.

\begin{tabular}{|c|c|c|c|c|c|c|c|c|}
\hline Site Name & $\mathbf{N}$ & $\mathbf{A}_{\mathbf{E}}$ & $\mathbf{H}_{\mathrm{E}}$ & $\mathrm{H}_{\mathbf{O}}$ & $\mathbf{P}_{\mathbf{a}}$ & $\mathbf{R}$ & & \\
\hline \multirow{2}{*}{ St. John’s Point (SJP) } & \multirow{2}{*}{19} & $3.44 \pm$ & $0.495 \pm$ & $0.480 \pm$ & $0.27 \pm$ & \multirow{2}{*}{0.94} & \multirow{2}{*}{0.0078} & \\
\hline & & 1.15 & 0.099 & 0.093 & 0.09 & & & \\
\hline \multirow{2}{*}{ Leitir Mealláin (LMN) } & \multirow{2}{*}{24} & $3.66 \pm$ & $0.470 \pm$ & $0.421 \pm$ & $0.09 \pm$ & \multirow{2}{*}{1.00} & \multirow{2}{*}{0.0107} & \\
\hline & & 1.22 & 0.092 & 0.092 & 0.03 & & & \\
\hline \multirow{2}{*}{ An Cheathrú Rua (ACR) } & \multirow{2}{*}{25} & $4.54 \pm$ & $0.467 \pm$ & $0.460 \pm$ & $0.11 \pm$ & \multirow{2}{*}{0.96} & \multirow{2}{*}{0.0954} & \\
\hline & & 1.51 & 0.089 & 0.100 & 0.04 & & & \\
\hline \multirow{2}{*}{ New Quay (NEQ) } & \multirow{2}{*}{23} & $3.65 \pm$ & & & & \multirow{2}{*}{1.00} & \multirow{2}{*}{-0.0093} & \\
\hline & & 1.22 & 0.099 & 0.079 & 0.07 & & & \\
\hline \multirow{2}{*}{ Newfy (NFY) } & \multirow[t]{2}{*}{25} & $2.92 \pm$ & $0.298 \pm$ & $0.297 \pm$ & $0.28 \pm$ & \multirow{2}{*}{1.00} & \multirow{2}{*}{-0.0266} & \\
\hline & & 0.97 & 0.087 & 0.094 & 0.09 & & & \\
\hline \multirow{2}{*}{ Bridges of Ross (BOR) } & \multirow{2}{*}{20} & $2.85 \pm$ & $0.283 \pm$ & $0.233 \pm$ & $0.24 \pm$ & \multirow{2}{*}{1.00} & \multirow{2}{*}{0.1321} & 0 \\
\hline & & 0.95 & 0.077 & 0.078 & 0.08 & & & \\
\hline \multirow{2}{*}{ Zetland Pier (ZET) } & \multirow{2}{*}{21} & $2.52 \pm$ & $0.380 \pm$ & $0.335 \pm$ & $0.10 \pm$ & \multirow{2}{*}{1.00} & \multirow{2}{*}{-0.0055} & o \\
\hline & & 0.84 & 0.103 & 0.104 & 0.03 & & & \\
\hline \multirow{2}{*}{ Lough Hyne (HYN) } & \multirow{2}{*}{23} & $8.17 \pm$ & $0.706 \pm$ & $0.536 \pm$ & $4.48 \pm$ & \multirow{2}{*}{1.00} & \multirow{2}{*}{0.3535} & \\
\hline & & 2.72 & 0.058 & 0.065 & 1.49 & & & \\
\hline
\end{tabular}

$\mathrm{N}$, number of thalli retained for subsequent analyses; $A_{E}$, allelic richness calculated using rarefaction based on a sample size of 19 diploids or 38 alleles; $H_{E}$, Nei's unbiased expected heterozygosity; $P_{a}$, private allelic richness calculated using rarefaction based on a sample size of 19 diploids or 38 alleles; $R$, genotypic richness calculated as $(\mathrm{R}-1) /(\mathrm{N}-1) ; \overline{r_{d},}$ single multilocus estimate of gametic disequilibrium (adjusted $p$-value $\left.=0.0009\right) ; F_{I S}$, inbreeding coefficient (adjusted $p$-value $=0.0007)$. 
Figure legends

Fig. 1. Sites where Laminaria hyperborea samples were collected in Ireland. SJP, St John's Point; LMN, Leitir Mealláin; ACR, An Cheathrú Rua; NEQ, New Quay; NFY, Newfy; BOR, Bridges of Ross; ZET, Zetland Pier; HYN, Lough Hyne.

Fig. 2. Genetic diversity estimates in Laminaria hyperborea across sites in Ireland. Expected heterozygosity $\left(H_{E}\right)$, allelic richness $\left(A_{E}\right)$, and private allelic richness $\left(P_{a}\right)$ by site. Dots are mean values and bars are standard errors of the mean. Means and errors were calculated over loci. Lines connecting sites are for visual comparison of values. SJP, St John's Point; LMN, Leitir Mealláin; ACR, An Cheathrú Rua; NEQ, New Quay; NFY, Newfy; BOR, Bridges of Ross; ZET, Zetland Pier; HYN, Lough Hyne.

Fig. 3. Isolation by distance of Laminaria hyperborea populations along the Irish coastline. Pairwise genetic differentiation, calculated as $F_{S T} /\left(1-F_{S T}\right)$, was regressed (intercept $=0.2315$, slope $=0.2539)$ against pairwise geographic distance $(\mathrm{km}, \log$ of $\mathrm{Km}$ shown $)$.

Fig. 4. DAPC relationships among microsatellite genotypes of Laminaria hyperborea. We colorcoded individuals corresponding to two sets of a priori groups with high reassignment frequencies (see Supplementary fig. 1): as a) by county; b) by county with two subregions for Galway (LMN, Leitir Mealláin; ACR, An Cheathrú Rua; NEQ, New Quay). The first two principal components are shown.

Fig. 5. Cluster assignment as inferred by instruct and visualized using clumpak and $R$ for optimal alignment of the 10 independent chains for $K=6$. The $\mathrm{x}$-axis is arranged by site from St. John's Point in County Donegal to Lough Hyne in County Cork (SJP, St John's Point; LMN, Leitir Mealláin; ACR, An Cheathrú Rua; NEQ, New Quay; NFY, Newfy; BOR, Bridges of Ross; ZET, Zetland Pier; HYN, Lough Hyne). The y-axis shows the proportion of each individual that 
belongs to a given genetic cluster. Colour-blind-friendly palette was chosen using "I want hue" (http://tools.medialab.sciences-po.fr/iwanthue/index.php, accessed 19 January 2019).

Fig. 6. DAPC relationships among microsatellite genotypes of Laminaria hyperborea in Ireland (our study) and France (Robuchon et al. 2014). The first two principal components are shown. 